\title{
Genetic Divergence Studies in Paprika (Capsicum annuum L.)
}

\author{
T. Lakshmi Tirupathamma ${ }^{1}$, L. Naram Naidu ${ }^{2}$, C. Venkata Ramana ${ }^{2 *}$ and K. Sasikala ${ }^{3}$ \\ ${ }^{1}$ Department of Vegetable Science, ${ }^{3}$ Department of Agronomy, College of Horticulture, Dr. \\ Y.S.R. Horticultural University, V.R. Gudem-534 101, India \\ ${ }^{2}$ Horticulture Research Station, Dr. Y.S.R. Horticultural University, Lam Farm, \\ Guntur-522 034, India \\ *Corresponding author
}

\section{A B S T R A C T}

Genetic divergence among forty four genotypes of paprika was assessed using Mahalanobis $\mathrm{D}^{2}$ statistic for twenty characters at Horticultural Research Station, Lam,

\begin{tabular}{|c|}
\hline Keywords \\
\hline $\begin{array}{l}\text { Capsicum annuиm } \mathrm{L} \text {., } \\
\text { Paprika, Mahalanobis } \mathrm{D}^{2} \\
\text { statistic, Tocher's method } \\
\text { of clustering, Genetic } \\
\text { divergence }\end{array}$ \\
\hline Article Info \\
\hline $\begin{array}{l}\text { Accepted: } \\
\text { 04 July } 2018 \\
\text { Available Online: } \\
\text { 10 August } 2018\end{array}$ \\
\hline
\end{tabular}
Guntur, Andhra Pradesh. The analysis of variance revealed significant differences among the genotypes for all the characters studied indicating considerable diversity in the material. Based on Mahalanobis $\mathrm{D}^{2}$ statistic, the forty four genotypes were grouped into 6 clusters. The maximum contribution towards genetic divergence was by total extractable colour $(21.56 \%)$ followed by red carotenoids (19.87\%), yellow carotenoids (13.95\%), ascorbic acid (7.29\%). Among the clusters, clusters III was the largest containing 17 genotypes followed by cluster II (15) and cluster I (9), whereas the clusters IV, V and VI were solitary clusters. The highest inter cluster distance was observed between cluster $\mathrm{V}$ and VI (1675.44), whereas the lowest was observed between cluster I and II (217.58). Cluster III (275.34) has exhibited highest intra cluster distance and the lowest was observed in clusters IV, V and VI (0.00), respectively. Cluster analysis by Tocher's method revealed wide genetic distance (inter cluster) between the genotypes of cluster $\mathrm{V}$ (Byadagikaddi) and the cluster VI (Warangal chapatta double patti) and the crossing between genotypes of these two clusters can be exploited for the development of heterotic hybrids in future breeding programmes.

\section{Introduction}

Paprika (Capsicum annuum L.), 2n = 24 a member of the Solanaceae family has originated from South and Central America. It is an indispensable spice due to its pungency, taste, appealing colour and flavor and has its unique place in the diet as a vegetable cum spice crop. Paprika, a form of chilli is mainly valued for its high colour, low or no pungency and oleoresins. India is the largest producer, consumer and exporter of chilli in the world with an annual production of 1.8 million tonnes from 0.83 million ha (NHB, 2016). Andhra Pradesh leads the country in its production, productivity and export followed by Karnataka, West Bengal, Madhya Pradesh and Orissa. 
Capsicinoids and carotenoids are the major chemical constituents of chilli fruits and add commercial value to the crop. The carotenoids contributing to fruit colour act as dietary precursors of vitamin A and play an important role in the regulation of vision, growth and reproduction. Among carotenoids 'capsanthin, capsorubin and capsanthin 5,6- epoxide are responsible for the final red colour (Davies et al., 1970). Pungency (heat) is an important quality attribute of hot pepper besides colour. The nature of pungency has been established as a mixture of seven closely related alkylvanillyl amides, collectively referred as "Capsaicinoids". Among capsiacinoids, capsaicin (8-methyl-N-vanillyl-6- enamide) and dihydrocapsaicin account for more than 80, determine the pungency (Bosland and Votava, 2000). The degree of pungency varies widely with the genotypes of five cultivated species (Kumar et al., 2006) and range from less than $0.05 \%$ in the mildly pungent types to as high as $1.3 \%$ in the hottest chillies. The 'capsaicin' is an alkaloid present in the placenta of the fruit, which can directly scavenge various free radicals (Reddy and Lokesh, 1992; Kogure et al., 2002; Bhattacharya et al., 2010) and has diverse prophylactic and therapeutic uses in Allopathic and Ayurvedic medicine (Sumathy and Mathew, 1984). The pharmaceutical application of capsaicinoids is attributed to its antioxidant, anticancer, antiarthritic and analgesic properties (Prasad et al., 2006).

Chilli is a good source of vitamin C (ascorbic acid) used in food and beverage industries (Bosland and Votava, 2000). It has also acquired a great importance because of the presence of 'oleoresin', which permits better distribution of color and flavor in foods. Apart from developing traditional varieties through conventional breeding, exploitation of heterosis for yield and yield attributing characters through hybridization is also important in crop improvement. Screening of available germplasm helps in studying the variability and diversity and identification of superior parents for use in hybridization. A wide variability in chilli fruit morphology, pungency, bearing habit and crop duration is found throughout India (Asati and Yadav, 2004). Genetic divergence existing in the population helps in the selection of suitable parents for utilization in any crop breeding programme leading to reduction in the number of crosses (Guerra et al., 1999). The information on the nature and degree of genetic divergence is essential for the breeder to choose the right type of parents for hybridization in heterosis breeding (Patel et al., 1989). Moreover, evaluation of genetic diversity is important to know the source of genes for a particular trait within the available germplasm (Tomooka, 1991). In order to benefit transgressive segregation, the knowledge of genetic distance between parents is necessary (Khodadabi et al., 2011). Hybrids produced from distantly related parents are expected to exhibit higher heterosis and minimize the inherent field genetic vulnerability (Moll et al., 1962; Ramanujam et al., 1974) than those from closely related parents. The knowledge of characters influencing divergence is important for a breeder to plan a successful breeding programme. Thus, the present study was undertaken to assess the genetic diversity in 44 genotypes of paprika (Capsicum annuum L.) and to identify suitable donors in respect of yield and quality for a successful breeding programme in this crop. Mahalanobis's D2 statistic of multivariate analysis is recognized as a powerful tool in quantifying the degree of genetic divergence among the populations and has been utilized in this study.

\section{Materials and Methods}

The experiment was carried out with 44 genotypes of paprika (Table 1) at Horticultural Research Station, Lam, Guntur, Andhra 
Pradesh, India. The site of the experiment at Lam is situated on 16.280 North latitude and 80.440 East longitude at an altitude of $31.5 \mathrm{~m}$ above mean sea level which falls under humid tropical climate and the soils of the experimental site are rich black cotton soils.

The genotypes studied in a randomized block design were replicated twice. The nursery was raised during first week of August and the seedlings were transplanted at a spacing of 75 $\mathrm{cm} \times 30 \mathrm{~cm}$ in a row $4 \mathrm{~m}$ length during first fortnight of September. Each row consisted of 12 plants, of which five competitive plants were selected at random for recording the observations. The crop was raised as per the recommended package of practices. The observations were recorded on plant height $(\mathrm{cm})$, plant spread $(\mathrm{cm})$, number of primary branches per plant, days to $50 \%$ flowering, days to maturity, number of fruits per plant, fruit length $(\mathrm{cm})$, fruit diameter $(\mathrm{cm})$, fruit pedicel length $(\mathrm{cm})$, number of seeds per fruit, weight of seeds per fruit, 1000 seed weight and dry fruit yield per plant(g), ascorbic acid (mg 100g-1), oleoresin content (\%), capsaicin content (SHU), total extractable colour (ASTA units), red carotenoids (\%), yellow carotenoids $(\%)$ and total carotenoids $(\%)$. The red ripe fruits were sun dried and ground in an electronic grinder and passed through a 0.5 $\mathrm{mm}$ sieve and the dry chilli powder was used to measure biochemical constituents except Vitamin ' $\mathrm{C}$ ' content, for which mature green fruits were used. The following procedures were used for estimating the biochemical constituents.

\section{Ascorbic acid (mg/100g)}

Ascorbic acid content of mature green fruits was estimated by volumetric method (Sadasivam and Balasubramanian, 1987). Dye solution was prepared by dissolving $42 \mathrm{mg}$ of sodium bicarbonate in distilled water taken into $200 \mathrm{ml}$ volumetric flask, to which $52 \mathrm{mg}$ of 2-6 dichlorophenol indophenol was added and the volume was made up to $200 \mathrm{ml}$ with distilled water. Stock solution was prepared by dissolving $100 \mathrm{mg}$ ascorbic acid in $100 \mathrm{ml}$ of $4 \%$ oxalic acid solution and $10 \mathrm{ml}$ of this stock solution was diluted to $100 \mathrm{ml}$ with $4 \%$ oxalic acid to get the working standard of 100 mg per ml.

$5 \mathrm{ml}$ of the working standard solution was pipetted into a $100 \mathrm{ml}$ of conical flask to which $10 \mathrm{ml}$ of $4 \%$ oxalic acid was added. The contents were titrated against the dye $\left(\mathrm{V}_{1} \mathrm{ml}\right)$ to get a pink end point. The chilli sample (5 g) was extracted in $4 \%$ oxalic acid and the volume was made up to $100 \mathrm{ml}$ and the contents were centrifuged. $5 \mathrm{ml}$ of this supernatant was pipetted out, to which $10 \mathrm{ml}$ of 4 per cent oxalic acid was added and titrated against the dye $\left(\mathrm{V}_{2} \mathrm{ml}\right)$. The ascorbic acid content was calculated using the formula given below

Ascorbic acid $(\mathrm{mg} / 100 \mathrm{~g})=\left(0.5 \mathrm{mg} \div \mathrm{V}_{1}\right) \times$ $\left(\mathrm{V}_{2} \div 5 \mathrm{ml}\right) \times(100 \mathrm{ml} \div \mathrm{Wt}$. of the sample $) \times$ 100

\section{Oleoresin content (\%)}

The oleoresin content was estimated as per the procedure given by Ranganna (1986). Finely mashed $25 \mathrm{~g}$ chilli powder was transferred to a glass column, which was plugged by cotton plug on its narrow end. A thin layer of cotton was placed over chilli powder in the glass column and $25 \mathrm{ml}$ of acetone was added. After all the acetone was decanted, $25 \mathrm{ml}$ acetone was added each time till a total of $250 \mathrm{ml}$ acetone was added to the contents. After decantation, the resulting red colored liquid in beaker contains all the principle constituents of chilli. The collected filtrate was transferred to a $250 \mathrm{ml}$ volumetric flask and the volume was made up with acetone. The chilli extract was transferred to a $250 \mathrm{ml}$ beaker of known weight $\left(\mathrm{W}_{\mathrm{I}} \mathrm{g}\right)$ and was kept in water bath at 
50- $60 \mathrm{oC}$ for $15-30$ minutes so that acetone gets evaporated. Then, weight of the beaker along with contents was recorded as $\mathrm{W}_{2} \mathrm{~g}$. The weight of the oleoresin content in the $25 \mathrm{~g}$ chilli powder was calculated and expressed in percentage using the given formula.

Oleoresin content $(\%)=\left(\left(\mathrm{W}_{2}-\mathrm{W}_{1)} \div\right.\right.$ Weight of sample) $\times 100$

\section{Capsaicin content (SHU)}

The capsaicin content of fruits was estimated by colorimetric method described by Bajaj et al., (1980). 0.5g dry chilli powder was weighed into glass-stoppered test tube; $10 \mathrm{ml}$ dry acetone (add 25g anhydrous sodium sulphate to $500 \mathrm{ml}$ of acetone at least one day before use) was added into the test tube and kept overnight for extraction. Next day samples were centrifuged at $10000 \mathrm{rpm}$ for $10 \mathrm{~min}$ to get clear supernatant. $1 \mathrm{ml}$ of the supernatant was taken into a test tube and evaporated to dryness in a hot water bath. Then, the residue was dissolved in $5 \mathrm{ml}$ of $0.4 \%$ of $\mathrm{NaOH}$ solution and $3 \mathrm{ml}$ of $3 \%$ phosphomolybdic acid was added. The contents were shaken and left undisturbed for $1 \mathrm{hr}$.

After $1 \mathrm{hr}$, the solution was quickly filtered into centrifuge tubes to remove any floating debris, and then centrifuged at $5000 \mathrm{rpm}$ for $15 \mathrm{~min}$. The clear blue coloured solution was directly transferred into the cuvette and absorbance was read at $650 \mathrm{~nm}$ along with a reagent blank. A standard graph was prepared using $0-200 \mu \mathrm{g}$ pure capsaicin. Simultaneously $0.2,0.4,0.6,0.8$ and $1 \mathrm{ml}$ of working standard solution (stock standard capsaicin solution was prepared by dissolving $50 \mathrm{mg}$ capsaicin in $50 \mathrm{ml}$ of $0.4 \% \mathrm{NaOH}$ solution $(1000 \mu \mathrm{g} / \mathrm{ml})$ and working standard solution prepared by diluting the $10 \mathrm{ml}$ of the stock standard to $50 \mathrm{ml}$ with $0.4 \% \mathrm{NaOH}$ solution $(200 \mu \mathrm{g} / \mathrm{ml}))$ was taken into new test tubes and proceeded as mentioned above. Per cent capsaicin calculated using the formula mentioned below

Capsaicin content $(\%)=(\mu \mathrm{g}$ capsaicin $\times 100 \times$ $100) \div(1000 \times 1000 \times 1 \times 0.5)$

Whereas, $1 \%=1,60,000$ SHU units

\section{Total extractable colour (ASTA units)}

Total extractable colour of fruits (ASTAAmerican Spice Trade Association units) was estimated as per the procedure given by Rosebrook et al., (1968). 100mg of sieved fine chilli powder was weighed into a volumetric flask. Acetone was added and flask was closed tightly with stopper, then contents were kept for $16 \mathrm{~h}$ at room temperature in dark and shaken intermittently. Solution was filtered using Whatman filter paper and final volume was made up to $100 \mathrm{ml}$. Absorbance of final extract was read at $460 \mathrm{~nm}$ using acetone as blank. ASTA color units were calculated as per the formula given below,

ASTA $=($ Absorbance at $460 \mathrm{~nm} \times 16.4) \div$ (Weight of sample in $\mathrm{g}$ )

\section{Determination of yellow and red fractions in chilli powder}

Total red (CR; capsanthin, capsorubin and capsanthin-5, 6- epoxide) and yellow (CY; zeaxanthin, violaxanthin, antheraxanthin, $\beta$ cryptoxanthin, $\beta$-carotene and cucurbita xanthin A) carotenoid isochromic fractions were estimated following protocol of spectrophotometric method (Hornero-Mendez and Minguez-Mosquera, 2001). Dried chilli fruits were ground into a fine powder and $100 \mathrm{mg}$ of dried powder was extracted four times with acetone until the complete exhaustion of the color. The extract was filtered and transferred to $50 \mathrm{ml}$ volumetric flask and the volume was made up with acetone. The samples absorbance was read at 
two wavelengths i.e., 472 and 508nm using acetone as blank. The red and yellow fractions were calculated using the following formulae.

$\mathrm{CR}(\mu \mathrm{g} / \mathrm{ml})=(\mathrm{A} 508 \times 2144.0)-(\mathrm{A} 472 \times$ $403.0) \div 270.9$

$\mathrm{CY}(\mu \mathrm{g} / \mathrm{ml})=(\mathrm{A} 472 \times 1724.3)-(\mathrm{A} 508 \times$ $2450.1) \div 270.9$

Total colour $=\mathrm{C}^{\mathrm{R}}+\mathrm{C}^{\mathrm{Y}}$

The analysis of variance was carried out as per the procedure given by Panse and Sukhatme (1985). The character contribution towards genetic divergence was computed using the method given by Singh and Chaudhary (1977). Percentage contribution towards genetic divergence was calculated using the following formula

Percentage contribution of the character $=(\mathrm{N}$ $\times 100) \div \mathrm{M}$ Where, $\mathrm{N}=$ Number of genotype combinations where the character was ranked first.

$\mathrm{M}=$ All possible combinations of number of genotypes considered.

The genetic divergence was worked out among the genotypes using Mahalanobis $\mathrm{D}^{2}$ statistics (Mahalanobis, 1936) and the $\mathrm{D}^{2}$ values were calculated as,

$\mathrm{D}_{\mathrm{ij}}^{2}=\sum_{t=1}\left(Y_{i}^{t}-Y_{j}^{t}\right)^{2}$

Where,

$Y_{i}^{t}$ is uncorrelated mean value of $i^{\text {th }}$ genotype for character ' $t$ '

$Y_{j}^{t}$ is uncorrelated mean value of $\mathrm{j}^{\text {th }}$ genotype for character ' $\mathrm{t}$ '
$D^{2}$ ij is $D^{2}$ between $i^{\text {th }}$ and $j^{\text {th }}$ genotypes.

The genotypes were grouped into different clusters by employing Tocher's method as outlined by Rao (1952). For grouping of genotypes, $\mathrm{D}^{2}$ values of all combinations of each genotype were arranged in ascending order of magnitude in a tabular form as described by Singh and Chaudhary (1977). To start with, two populations having the closest distance from each other were considered, to which the third population having the smallest $\mathrm{D}^{2}$ value from the first two populations was added.

Similarly, the next nearest fourth population was considered and this procedure was continued. At certain stage when it was felt that after adding a particular population there was an abrupt increase in the average $\mathrm{D}^{2}$, that population was not considered for including in that cluster.

The genotypes of the first cluster were then eliminated and the rest were treated in a similar way. This procedure was continued till all the genotypes were included into one or other cluster.

The average intra and inter cluster distances were calculated by the formula given by Singh and Chaudhary (1977).

Square of intra- cluster distance $=\Sigma \mathrm{Di}^{2} / \mathrm{n}$

Square of inter- cluster distance $=\Sigma \mathrm{Di}^{2} /$ ninj Where,

$\Sigma \mathrm{Di}^{2}=$ Sum of distance between all possible combinations.

$\mathrm{n}=$ Number of all possible combinations

$\mathrm{ni}=$ Number of entries in clusteri

$n j=$ Number of entries in clusterj 


\section{Results and Discussion}

The analysis of variance (ANOVA) revealed significant differences among 44 genotypes for quantitative and qualitative traits indicating the existence of variability among genotypes for characters studied (Table 2).

These findings are in accordance with the results of many earlier works (Farhad et al., 2010; Kumar et al., 2010; Shrilekha et al., 2011; Tasso et al., 2014 Janaki et al., 2016).

The per cent contribution towards genetic divergence by all the 20 contributing characters is presented in Table 3 and Figure 1. The maximum contribution towards genetic divergence was by total extractable colour $(21.56 \%)$ followed by red carotenoids (19.87\%), yellow carotenoids (13.95\%), ascorbic acid (7.29\%) and dry fruit yield per plant (7.29\%), oleoresin content (6.98\%), capsaicin content $(6.87 \%)$, weight of seeds per fruit $(5.92 \%), 1000$ seed weight $(4.33 \%)$, fruit diameter $(2.96 \%)$, number of fruits per plant and fruit length $(1.06 \%)$, number of seeds per fruit $(0.42 \%)$, fruit pedicel length $(0.21 \%)$, days to 50 per cent flowering and total carotenoids $(0.11 \%)$, plant height, plant spread, number of primary branches per plant and days to maturity $(0.01 \%)$. Hence, selection for divergent parents based on these characters will be useful for heterosis breeding in paprika.

The 44 genotypes were grouped into six clusters using the Tocher's method (Table 4 and Figure 2) with the criterion that the intracluster average $\mathrm{D}^{2}$ values should be less than the inter-cluster $\mathrm{D}^{2}$ values. The distribution of 44 genotypes into 6 clusters was at random with maximum number of genotypes were grouped in cluster III (17 genotypes) from different locations followed by cluster II with 15 genotypes as the second largest followed by cluster I with 9 genotypes. Whereas, clusters IV, V and VI were solitary in nature i.e., one genotype in each cluster (LCA 480, Byadagi Kaddi, Warangal chapata double patti respectively). The formation of distinct solitary clusters may be due to the fact that geographic barriers preventing gene flow and intensive natural and human selection for diverse and adoptable gene complexes must be responsible for this genetic diversity.

The pattern of grouping of genotypes into different clusters was random and indicated that there is no parallelism between genetic divergence and geographical divergence of genotypes.

Therefore, selection of genotypes for hybridization should be based on genetic diversity rather than geographical diversity. Vani et al., (2007) reported fourteen clusters with 55 genotypes, Dutonde et al., (2008) observed seven clusters with 40 accessions, Farhad et al., (2010) reported six clusters with 45 chilli genotypes, Shrilekha et al., (2011) reported seven clusters with 38 genotypes, Lahbib et al., (2012) grouped 11 landraces into three clusters, Tassoet al., (2014) observed six clusters with 30 chilli genotypes, Hasan et al.,(2014) observed seven clusters with 54 chilli genotypes and Rana et al., (2015) reported three clusters with 24 genotypes and Razzaq et al., (2016) observed five clusters with 25 chilli genotypes and Janaki et al., (2016) reported eight clusters with 63 genotypes and these findings support the results of this investigation.

The intra and inter- cluster distance represent the index of genetic diversity among clusters (Table 5 and Figure 3). Of the 6 clusters formed, the mean intra-cluster D2 distance values ranged from a minimum of 0.00 (Clusters IV, V and VI) to a maximum of 275.34 (Cluster III). The intra cluster distance in other clusters viz., cluster II (179.33) and cluster I (102.55) was in between this range. 
Table.1 List of paprika genotypes used in the experiment and their source

\begin{tabular}{|c|c|c|c|c|}
\hline Treatment & $\begin{array}{l}\text { Accession } \\
\text { Number }\end{array}$ & Treatment & Accession Number & Source \\
\hline $\mathbf{T}_{1}$ & LCA 445 & $\mathrm{~T}_{23}$ & LCA 465 & HRS, Lam farm, Guntur \\
\hline $\mathbf{T}_{2}$ & LCA 447 & $\mathrm{~T}_{24}$ & LCA 475 & HRS, Lam farm, Guntur \\
\hline $\mathbf{T}_{3}$ & LCA 439 & $\mathrm{~T}_{25}$ & LCA 488 & HRS, Lam farm, Guntur \\
\hline $\mathbf{T}_{4}$ & LCA 442 & $\mathrm{~T}_{26}$ & LCA 499 & HRS, Lam farm, Guntur \\
\hline $\mathbf{T}_{5}$ & LCA 430 & $\mathrm{~T}_{27}$ & LCA 506 & HRS, Lam farm, Guntur \\
\hline$T_{6}$ & LCA 457 & $\mathrm{~T}_{28}$ & LCA 503 & HRS, Lam farm, Guntur \\
\hline $\mathbf{T}_{7}$ & LCA 443 & $\mathrm{~T}_{29}$ & LCA 490 & HRS, Lam farm, Guntur \\
\hline $\mathbf{T}_{8}$ & LCA 437 & $\mathrm{~T}_{30}$ & LCA 501 & HRS, Lam farm, Guntur \\
\hline$T_{9}$ & LCA 453 & $\mathrm{~T}_{31}$ & LCA 504 & HRS, Lam farm, Guntur \\
\hline$T_{10}$ & LCA 450 & $\mathrm{~T}_{32}$ & LCA 510 & HRS, Lam farm, Guntur \\
\hline$T_{11}$ & LCA 441 & $\mathrm{~T}_{33}$ & LCA 510 & HRS, Lam farm, Guntur \\
\hline $\mathbf{T}_{12}$ & LCA 425 & $\mathrm{~T}_{34}$ & LCA 511 & HRS, Lam farm, Guntur \\
\hline $\mathbf{T}_{13}$ & LCA 440 & $\mathrm{~T}_{35}$ & LCA 512 & HRS, Lam farm, Guntur \\
\hline$T_{14}$ & LCA 446 & $\mathrm{~T}_{36}$ & LCA 513 & HRS, Lam farm, Guntur \\
\hline$T_{15}$ & LCA 470 & $\mathrm{~T}_{37}$ & $\begin{array}{l}\text { Warangal chappatta } \\
\text { single patti }\end{array}$ & HRS, Lam farm, Guntur \\
\hline$T_{16}$ & LCA 436 & $\mathrm{~T}_{38}$ & $\begin{array}{l}\text { Warangal chappatta } \\
\text { double patti }\end{array}$ & HRS, Lam farm, Guntur \\
\hline $\mathbf{T}_{17}$ & LCA 466 & $\mathrm{~T}_{39}$ & Byadagikaddi & HRS, Lam farm, Guntur \\
\hline$T_{18}$ & LCA 472 & $\mathrm{~T}_{40}$ & Byadagidabbi & HRS, Lam farm, Guntur \\
\hline$T_{19}$ & LCA 476 & $\mathrm{~T}_{41}$ & $\mathrm{Kt}-1$ & HRS, Lam farm, Guntur \\
\hline$T_{20}$ & LCA 480 & $\mathrm{~T}_{42}$ & $\begin{array}{l}\text { Jangareddygudem } \\
\text { local }\end{array}$ & HRS, Lam farm, Guntur \\
\hline$T_{21}$ & LCA 482 & $\mathrm{~T}_{43}$ & LCA 436 & HRS, Lam farm, Guntur \\
\hline$T_{22}$ & LCA 498 & $\mathrm{~T}_{44}$ & LCA 424 & HRS, Lam farm, Guntur \\
\hline
\end{tabular}


Table.2 Analysis of variance for various characters in paprika (Capsicum annuиm L.)

\begin{tabular}{|c|c|c|c|c|}
\hline S. No. & Character & Replic & $\begin{array}{l}\text { in sum of square } \\
\text { ions Genotypes }\end{array}$ & Sror \\
\hline 1 & Plant height (cm) & 0.16 & $257.11 * *$ & 122.38 \\
\hline 2 & Plant spread (cm) & 12.45 & $698.05 * *$ & 187.34 \\
\hline 3 & $\begin{array}{l}\text { Number of primary branches per } \\
\text { plant }\end{array}$ & 0.02 & $0.17 * *$ & 0.04 \\
\hline 4 & Days to 50 per cent flowering & 0.40 & $52.46 * *$ & 12.59 \\
\hline 5 & Days to maturity & 405.92 & $840.97 * *$ & 121.33 \\
\hline 6 & Number of fruits per plant & 78.09 & $2217.27 * *$ & 97.27 \\
\hline 7 & Fruit length $(\mathrm{cm})$ & 2.10 & $10.32 * *$ & 0.78 \\
\hline 8 & Fruit diameter (cm) & 0.13 & $2.92 * *$ & 0.11 \\
\hline 9 & Fruit pedicel length $(\mathrm{cm})$ & 0.20 & $0.68 * *$ & 0.13 \\
\hline 10 & Number of seeds per fruit & 192.63 & $1204.12 * *$ & 85.28 \\
\hline 11 & Weight of seeds per fruit (g) & 0.001 & $0.09 * *$ & 0.004 \\
\hline 12 & 1000 seed weight $(\mathrm{g})$ & 1.73 & $16.86 * *$ & 0.73 \\
\hline 13. & Ascorbic acid (mg/100g) & 145.89 & $4674.56^{* *}$ & 151.61 \\
\hline 14 & Oleoresin content $(\%)$ & 0.53 & $16.66 * *$ & 0.66 \\
\hline 15 & Capsaicin content (SHU) & 1784670.75 & $36198080.00 * *$ & 157919.25 \\
\hline 16 & $\begin{array}{l}\text { Total extractable colour (ASTA } \\
\text { units) }\end{array}$ & 22.99 & $2376.67 * *$ & 115.58 \\
\hline 17 & Red carotenoids (\%) & 0.0005 & $0.02 * *$ & 0.0007 \\
\hline 18 & Yellow carotenoids (\%) & 0.00004 & $0.015 * *$ & 0.0009 \\
\hline 19 & Total carotenoids (\%) & 0.0003 & $0.03 * *$ & 0.0019 \\
\hline 20 & Dry fruit yield per plant (g) & 0.10 & $2316.47 * *$ & 178.91 \\
\hline
\end{tabular}

*: Significant at 5 per cent level; **: Significant at 1 per cent level 
Table.3 Relative contribution of different characters towards genetic divergence in paprika (Capsicum annuum L.)

\begin{tabular}{|l|l|l|l|}
\hline S. No. & Source & Times ranked 1 $^{\text {st }}$ & Contribution \% \\
\hline $\mathbf{1}$ & Plant height $(\mathrm{cm})$ & 0 & 0.01 \\
\hline $\mathbf{2}$ & Plant spread $(\mathrm{cm})$ & 0 & 0.01 \\
\hline $\mathbf{3}$ & Number of primary branches per plant & 0 & 0.01 \\
\hline $\mathbf{4}$ & Days to 50 per cent flowering & 1 & 0.11 \\
\hline $\mathbf{5}$ & Days to maturity & 0 & 0.01 \\
\hline $\mathbf{6}$ & Number of fruits per plant & 10 & 1.06 \\
\hline $\mathbf{7}$ & Fruit length (cm) & 10 & 1.06 \\
\hline $\mathbf{8}$ & Fruit diameter $(\mathrm{cm})$ & 28 & 2.96 \\
\hline $\mathbf{9}$ & Fruit pedicel length (cm) & 2 & 0.21 \\
\hline $\mathbf{1 0}$ & Number of seeds per fruit & 4 & 0.42 \\
\hline $\mathbf{1 1}$ & Weight of seeds per fruit $(\mathrm{g})$ & 56 & 5.92 \\
\hline $\mathbf{1 2}$ & 1000 seed weight (g) & 41 & 4.33 \\
\hline $\mathbf{1 3}$ & Ascorbic acid (mg /100g) & 69 & 7.29 \\
\hline $\mathbf{1 4}$ & Oleoresin content (\%) & 66 & 6.98 \\
\hline $\mathbf{1 5}$ & Capsaicin content (SHU) & 65 & 6.87 \\
\hline $\mathbf{1 6}$ & Total extractable colour (ASTA units) & 204 & 21.56 \\
\hline $\mathbf{1 7}$ & Red carotenoids (\%) & 188 & 19.87 \\
\hline $\mathbf{1 8}$ & Yellow carotenoids (\%) & 132 & 13.95 \\
\hline $\mathbf{1 9}$ & Total carotenoids (\%) & 1 & 0.11 \\
\hline $\mathbf{2 0}$ & Dry fruit yield per plant (g) & 69 & 7.29 \\
\hline
\end{tabular}

\section{Table.4 Clustering of 44 paprika (Capsicum annuum L.) genotypes by Tocher's method}

\begin{tabular}{|c|c|c|}
\hline Cluster & No. of genotypes & Name of genotypes \\
\hline I & 9 & $\begin{array}{l}\text { LCA } 445 \text {, LCA } 472, \text { LCA } 442, \text { LCA } 470, \text { LCA } 503 \text {, LCA } 430, \text { LCA } 499 \text {, } \\
\text { LCA } 457 \text {, LCA } 425 .\end{array}$ \\
\hline II & 15 & $\begin{array}{l}\text { LCA } 488 \text {, LCA } 501 \text {, LCA } 447 \text {, LCA } 504 \text {, LCA } 506 \text {, LCA } 441 \text {, LCA } 439 \text {, } \\
\text { LCA } 437 \text {, LCA } 475 \text {, LCA } 465 \text {, LCA 466, LCA513, LCA } 482 \text {, } \\
\text { Byadagidabbi, LCA } 450\end{array}$ \\
\hline III & 17 & $\begin{array}{l}\text { LCA 511, Warngalchappatta single patti, LCA 512, LCA 498, LCA 440, } \\
\text { LCA 510, LCA 510, LCA 476, Kt-1, LCA 436, LCA 446, LCA 490, } \\
\text { LCA 453, LCA 443, Jangareddygudem local, LCA 424, LCA } 436\end{array}$ \\
\hline IV & 1 & LCA 480 \\
\hline $\mathbf{V}$ & 1 & Byadagikaddi \\
\hline VI & 1 & Warangal chappatta double patti \\
\hline
\end{tabular}

Table.5 Average intra (bold) and inter cluster $\mathrm{D}^{2}$ values of six clusters in paprika (Capsicum annuum L.)

\begin{tabular}{|l|l|l|l|l|l|l|}
\hline Cluster & $\mathbf{1}$ Cluster & $\mathbf{2}$ Cluster & $\mathbf{3}$ Cluster & $\mathbf{4}$ Cluster & $\mathbf{5}$ Cluster & 6 Cluster \\
\hline I & $\mathbf{1 0 2 . 5 5}$ & 217.58 & 281.96 & 400.09 & 338.74 & 1034.49 \\
\hline II & & $\mathbf{1 7 9 . 3 3}$ & 320.78 & 246.35 & 275.43 & 1124.39 \\
\hline III & & & $\mathbf{2 7 5 . 3 4}$ & 429.56 & 481.32 & 886.88 \\
\hline IV & & & & $\mathbf{0 . 0 0}$ & 359.58 & 1414.04 \\
\hline V & & & & & $\mathbf{0 . 0 0}$ & 1675.44 \\
\hline VI & & & & & & $\mathbf{0 . 0 0}$ \\
\hline
\end{tabular}


Table.6 Mean performance of yield per plant and its component characters in various clusters of paprika (Tocher's method)

\begin{tabular}{|c|c|c|c|c|c|c|c|c|c|c|c|c|c|c|c|c|c|c|c|c|}
\hline $\begin{array}{l}\text { Cluster } \\
\text { No. }\end{array}$ & PH & PS & NPBP & DFF & DM & NFP & FL & FD & FPL & NSP & WSP & $\begin{array}{l}1000 \\
\text { SW }\end{array}$ & $\mathbf{A A}$ & OC & $\mathrm{CC}$ & TEC & $\mathbf{R C}$ & YC & TC & DFYP \\
\hline \multirow[t]{2}{*}{$\mathbf{I}$} & & & & & & & & & & & & & & & & & & & & \\
\hline & 89.10 & 132.77 & 3.64 & 61.33 & 135.77 & 165.21 & 13.17 & 4.66 & 4.05 & 71.62 & 0.49 & 3.80 & 55.74 & 6.95 & 6959.77 & 134.25 & 0.22 & 0.13 & 0.36 & 150.88 \\
\hline \multirow[t]{2}{*}{ II } & & & & & & & & & & & & & & & & & & & & \\
\hline & 85.80 & 124.57 & 3.44 & 61.73 & 137.56 & 168.43 & 12.06 & 4.20 & 3.55 & 57.81 & 0.38 & 5.65 & 94.80 & 8.21 & 8544.80 & 99.05 & 0.14 & 0.26 & 0.41 & 130.53 \\
\hline \multirow[t]{2}{*}{ III } & & & & & & & & & & & & & & & & & & & & \\
\hline & 92.17 & 130.38 & 3.62 & 58.14 & 130.20 & 141.38 & 10.42 & 4.80 & 3.34 & 76.48 & 0.55 & 6.59 & 103.11 & 9.72 & 11810.79 & 105.71 & 0.22 & 0.17 & 0.40 & 118.79 \\
\hline \multirow[t]{2}{*}{ IV } & & & & & & & & & & & & & & & & & & & & \\
\hline & 83.10 & 132.40 & 4.00 & 61.00 & 138.00 & 197.10 & 11.55 & 4.85 & 3.90 & 53.90 & 0.32 & 2.59 & 167.31 & 11.50 & 4552.00 & 61.81 & 0.06 & 0.13 & 0.19 & 144.00 \\
\hline \multirow[t]{2}{*}{$\overline{\mathbf{V}}$} & & & & & & & & & & & & & & & & & & & & \\
\hline & 83.30 & 141.10 & 4.00 & 52.50 & 97.50 & 118.70 & 16.80 & 2.55 & 3.70 & 45.40 & 0.25 & 8.40 & 181.40 & 11.35 & 6052.50 & 115.00 & 0.16 & 0.26 & 0.42 & 82.00 \\
\hline \multirow[t]{2}{*}{$\begin{array}{l}\text { VI } \\
\end{array}$} & & & & & & & & & & & & & & & & & & & & \\
\hline & 91.80 & 117.80 & 3.40 & 59.00 & 112.00 & 120.50 & 8.30 & 9.70 & 2.40 & 154.00 & 1.35 & 18.10 & 72.93 & 14.55 & 5463.00 & 147.35 & 0.16 & 0.25 & 0.41 & 95.00 \\
\hline
\end{tabular}

Bold values indicate maximum and minimum mean performance

Note: PH - Plant height (cm), PS-Plant spread (cm), NPBP - Number of primary branches per plant, DFF - Days to 50 per cent flowering, DM- Days to maturity, NFP - Number of fruits per plant, FL - Fruit length $(\mathrm{cm})$, FD - Fruit diameter $(\mathrm{cm})$, FPL- Fruit pedicel length $(\mathrm{cm})$, NSF - Number of seeds per fruit, WSF- Weight of seeds per fruit (g), 1000 SW- 1000 Seed weight (g), AA-Ascorbic acid(mg/100mg), OC - Oleoresin content (\%), CC - Capsaicin content (SHU),TEC- Total extractable colour (ASTA units), RC- Red carotenoids (\%), YC- Yellow carotenoids (\%), TC- Total carotenoids (\%), DFYP - Dry fruit yield per p lant $(\mathrm{g})$. 
Fig.1 Relative contribution of different characters towards genetic divergence in paprika

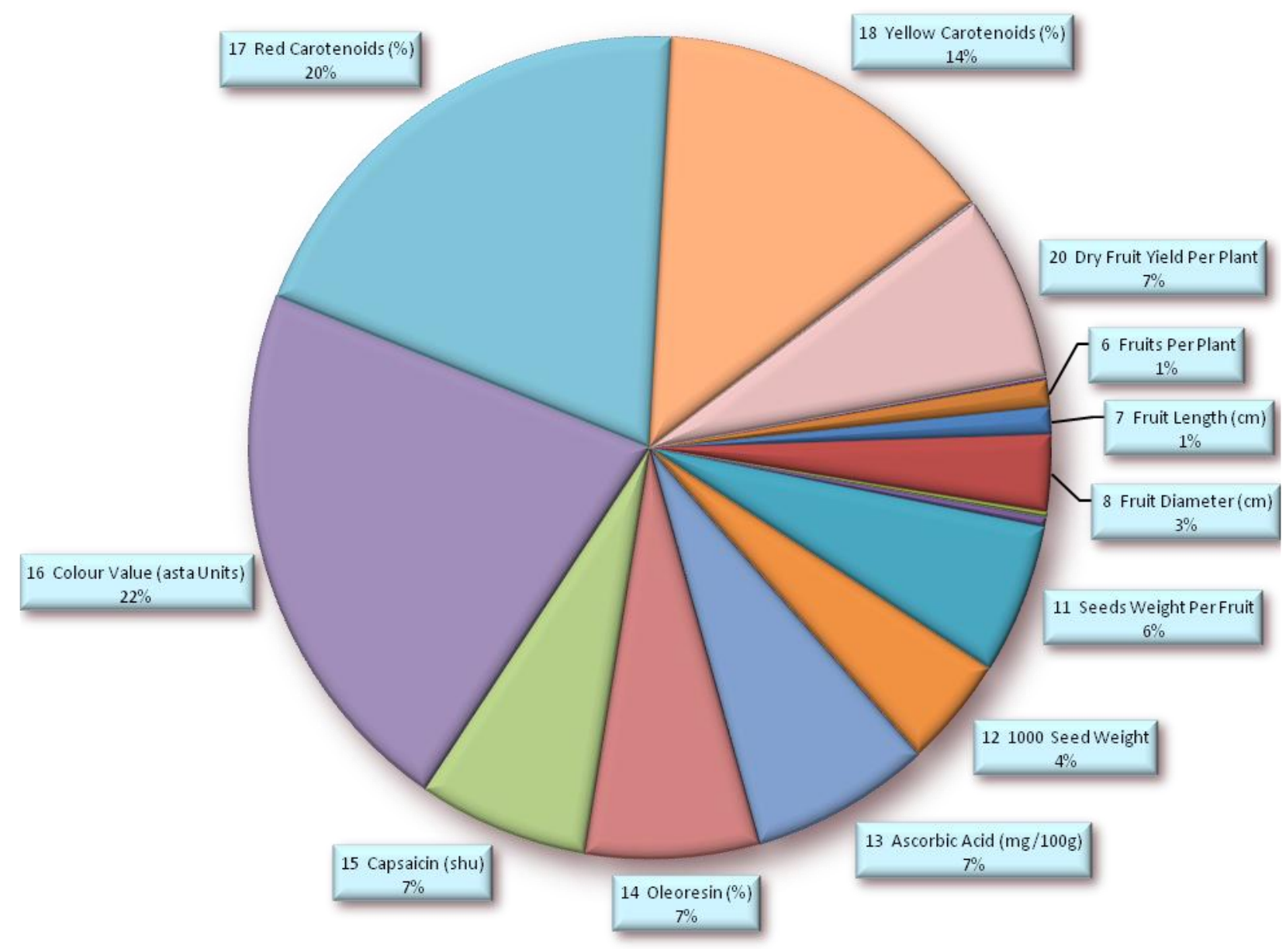


Fig.2 Dendrogram showing clustering pattern of 44 paprika (Capsicum annuum L.) genotypes (Tocher's method)

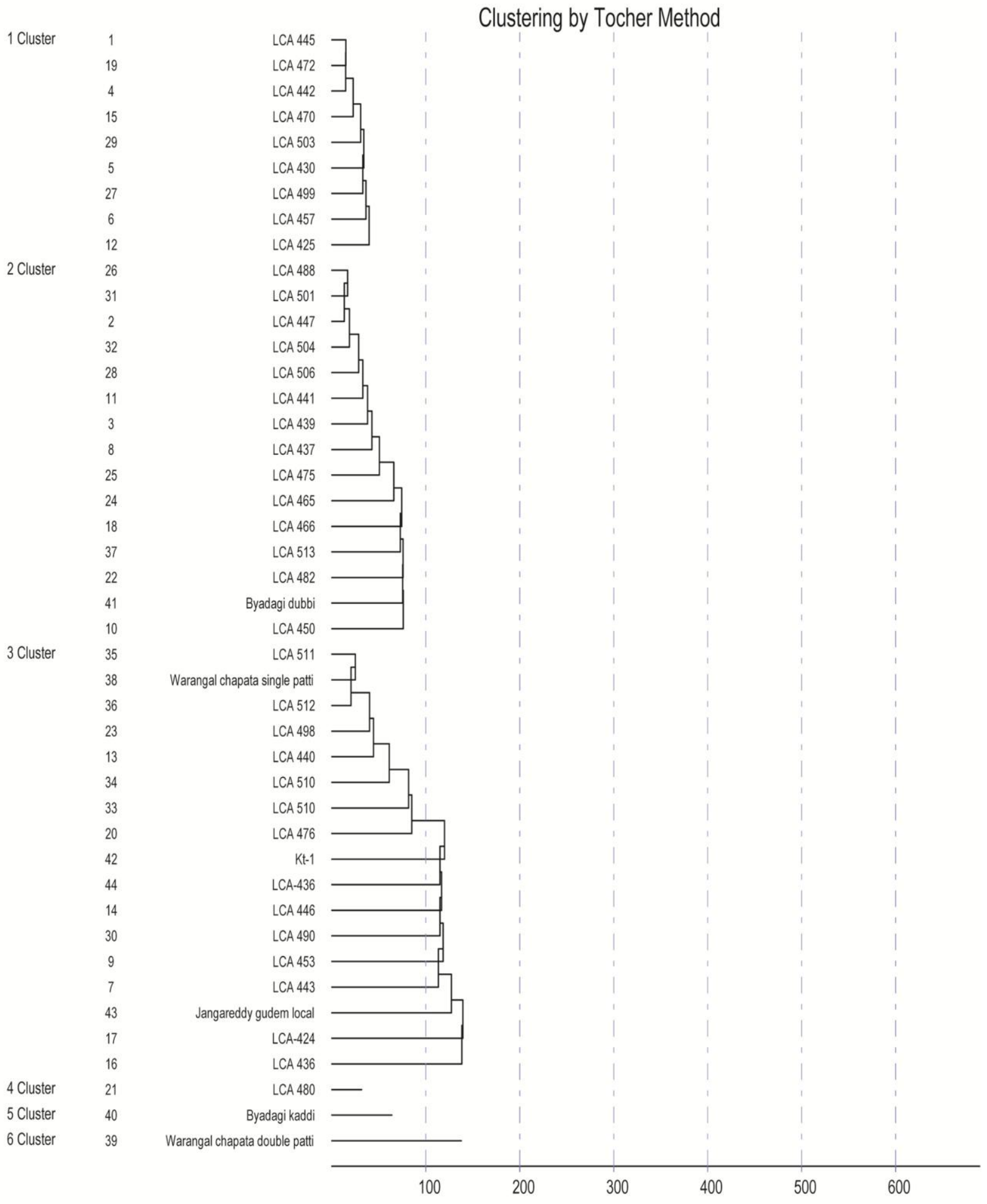


Fig.3 Average intra and inter cluster $\mathrm{D}^{2}$ values of six clusters in paprika (Capsicum annuиm $\mathrm{L}$.)

\section{Tocher Method}

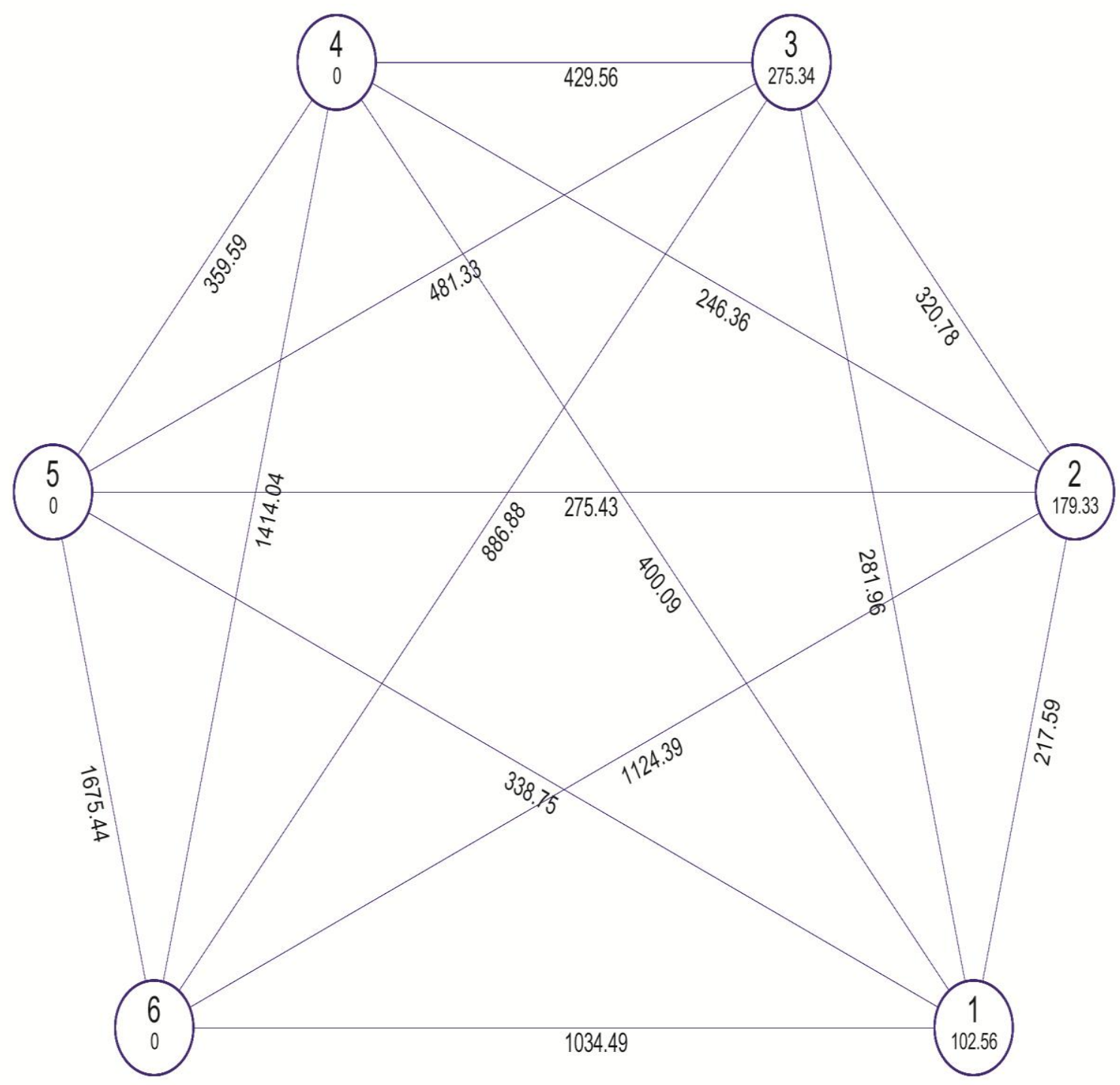

Mahalnobis Euclidean Disatnce (Not to the Scale)

The high intra-cluster distance in cluster III indicates the presence of genetic diversity among the genotypes present of the same cluster. The maximum inter-cluster distance was observed between cluster $\mathrm{V}$ and VI (1675.44) followed by cluster IV and VI (1414.04) and cluster II and VI (1124.39) and cluster I and VI (1034.49) and cluster III and VI (886.88). The hybrids of distant genotypes are reported to yield better (Kumar et al., 2010) and thus crosses between the genotypes from cluster V and VI can be used in chilli breeding to achieve maximum heterosis and to obtain heterotic hybrids and desirable 
segregants. The minimum inter-cluster distance was observed between genotypes of cluster I and II (217.58) which can be used for backcrossing programmes. The genotypes of cluster II and IV (246.35), cluster II and V (275.43) and cluster I and III (281.96) also have recorded minimum inter-cluster distance. The lowest inter-cluster distance between these cluster pairs suggested close proximity of genotypes of one cluster with those of the other cluster in respect of their genetic constitution. Several earlier reports (Mishra et al., 2004; Ajjapplavara, 2009; Kumar et al., 2010; Suryakumari et al., 2010; Pandit et al., 2010, Tasso et al., 2014, Janaki et al., 2016, Rana et al., 2015; Razzaq et al., 2016) also indicate the presence of a high genetic divergence among chilli genotypes in their respective experiments. The genotypes grouped into the same cluster presumably diverge very little from one another and crossing of genotypes belonging to the same cluster is not expected to yield desirable segregants. Consequently, a crossing programme should be conducted with putative parents. Thus, crosses between the members of clusters separated by inter-cluster distances are likely to be beneficial for further improvement. D2 cluster analysis revealed wide genetic distance (inter cluster) between the genotypes of cluster $\mathrm{V}$ (Byadagikaddi) and the cluster VI (Warangal chappatta double patti. The crossing between genotypes of cluster V \& VI can be exploited for the development of heterotic hybrids in future breeding programmes.

Cluster I earned highest cluster mean value for fruit pedicel length (4.05), red caroteniods (0.22) and dry fruit yield per plant (150.88) and lowest cluster mean value for ascorbic acid (55.74) and oleoresin content (6.95) (Table 6). On the other hand, Cluster II produced highest mean value for days to 50 per cent flowering (61.73) and yellow caroteniods $(0.26)$. Cluster III had the highest mean value for plant height (92.17) and capsaicin content (11810.79) and cluster IV showed highest mean value for no. of primary branches per plant (4.00), days to maturity (138.00), number of fruits per plant (197.10) and lowest mean value for plant height (83.10), 1000 seed weight (2.59), capsaicin content (4552.00), total extractable colour (61.81), red (0.06), yellow (0.13) and total carotenoids (0.19) and cluster $\mathrm{V}$ recorded highest mean value for plant spread (141.10), no. of primary branches per plant (4.00), fruit length (16.80), ascorbic acid (181.40) and yellow (0.26) and total (0.42) carotenoids and had lowest mean value for days to 50 per cent flowering (52.50), days to maturity (97.50), number of fruits per plant (118.70), fruit diameter (2.55), number of seeds per fruit (45.40), weight of seeds per fruit (0.25) and yield per plant (82.00) and cluster VI had highest mean value for fruit diameter (9.70), number of seeds per fruit (154.00), weight of seeds per fruit (1.35), 1000 seed weight (18.10), oleoresin content (14.55), total extractable colour (147.35) and had lowest mean value for plant spread (117.80), no. of primary branches per plant (3.40), fruit length (8.30) and fruit pedicel length (2.40). The genotypes in cluster I were recorded higher yield. Genotypes of clusters V and VI showed better performance for quality traits. These clusters can be used in breeding programme for introgression of their desired quality genes into the high yielding varieties.

D2 cluster analysis revealed wide genetic distance (inter cluster) between the genotypes of cluster V (Byadagikaddi) and the cluster VI (Warangal chappatta double patti). The crossing between genotypes of cluster $\mathrm{V}$ and VI can be exploited for the development of heterotic hybrids in future breeding programmes. The clusters V, VI, IV, I and II were found superior for one or more characters. Therefore, a multiple crossing programme can be proposed involving 
genotypes from these clusters for the development of superior segregants in advanced generations with high yield potential combined with better quality in paprika

\section{Acknowledgements}

I extend my deep sense of reverence and gratitude to Associate Dean, College of Horticultural and Research Institute, Venkataramannagudem, Dr. Y.S.R.H.U for allotting me to HRS, Lam to take up my research work. I am highly thankful to Dr. Y.S.R. Horticultural University, Venkataramannagudem for providing financial assistance in the form of stipend to complete this endeavour

\section{References}

Ajjapplavara, P.S. 2009.Genetic diversity in chilli (Capsicum annuum L.). The Asian Journal of Horticulture. 4(1): 29-31.

Asati, B.S and Yadav, D.S. 2004. Diversity of horticultural crops in north eastern region. ENVIS Bulletin: Himalayan Ecology. 12 (2): 1-11.

Bajaj, K.L., Kaur, G and Sooch, B. 1980 Varietal variation in some important chemical constituents in chilli (Capsicum annuum L.) fruits. Vegetable Science.7: 48-54.

Bhattacharya, A., Chattopadhyay, A., Mazumdar, D., Chakravarty, A and Pal, S. 2010 Antioxidant constituents and enzyme activities in chilli peppers. International Journal of Vegetable Science. 16: 201- 211.

Bosland, P.W and Votava, E.J. 2000. Peppers: Vegetable and spice capsicums. CABI Publishing, CAB International, Walingfort, U.K.

Davies, B.H., Matthews, S and Kirk, J.T.O. 1970. The nature and biosynthesis of the carotenoids of different colour varieties of Capsicum annuum L. Phytochemistry.9: 797-805.

Dutonde, S.N., Bhalekar, M.N., Patil, B.T., Kshirsagar, D.B and Dhumal, S.S. 2008. Genetic diversity in chilli (Capsicum annuum L.). Agricultural Science Digest. 28 (1):45-47.

Farhad, M., Hasanuzzaman, M., Biswas, B.K., Arifuzzaman, M. and Islam, M.M. (2010). Genetic divergence in chilli (Capsicum annum L.). Bangladesh Research Publications Journal. 3(3): 1045- 1051.

Guerra, E.P., Destro, D., Miranda, L.A and Montalvan, R. 1999. Parent selection for intercrossing in food type soybean through multivariate genetic divergence. The Acta Scientiarum. 21(3): 429- 437.

Hasan, M.J, Kulsum, M.U, Ullah, M.Z, Manzur Hossain, $\mathrm{M}$ and Eleyash Mahmud, M. 2014. Genetic diversity of some chili (capsicum annuum L.) genotypes. International Journal of Agricultural Research, Innovation and Technology. 4 (1): 32-35.

Hornero-Mendez, D and Minguez-Mosquera, I.M. 2001. Rapid spectrophotometric determination of red and yellow isochromic carotenoid fractions in paprika and red pepper oleoresins. Journal of Agricultural and Food Chemistry. 49: 3584-3588.

Janaki, M, Naram, N.L, Venkata, R.C and Paratpara, R. M. 2016. Genetic divergence among chilli (capsicum annuиm L.). Genotypes based on quantitative and qualitative traits. International Journal of Science and Nature.7 (1): 181-189.

Khodadabi, M., Fotokian, M.H and Miransari, M. 2011. Genetic diversity of wheat genotypes based on cluster and principal component analysis for breeding strategies. Australian Journal of Crop Science. 5(1): 17-24. 
Kogure, K., Goto, S., Nishimura, M., Yasumoto, M., Abe, K and Ohiwa, L. 2002. Mechanism of potent antiperoxidative effect of capsaicin. Biochimicaet BiophysicaActa. 1573 (1): 84-92.

Kumar, D.B.M., Anand, K and Mallikarjunaiah, H. 2010.Genetic divergence in chilli accessions. Electronic Journal of Plant Breeding. 1(5): 1363-1366.

Kumar, S., Kumar, R., and Singh, J. 2006. Cayenne/American pepper (Capsicum species). In: Peter KV (ed), Handbook of herbs and spices. Vol3.WoodheadPubl, Cambridge, UK, pp299-312.

Lahbib, K., Bnejdi, F and Mohamed, El. G. 2012. Genetic diversity evaluation of pepper (Capsicum annuum L.) in Tunisia based on morphologic characters. African Journal of Agricultural Research. 7: 3413- 3417.

Mahalanobis, P.C. 1936. On the generalized distance in statistics. Proceedings of National Academic Science. 2. 55-79.

Mishra, A.C., Singh, R.V and Ram, H.H. 2004. Studies on genetic divergence in capsicum (Capsicum annuum L.) in Uttaranchal. Capsicum and Eggplant Newsletter. 23: 45-48.

Moll, R.H., Salhwana, W.S and Robinson, H.F. 1962. Heterosis and genetic diversity in variety crosses in maize. Crop Science. 2: 197-198.

National Horticulture Board. 2013. Indian Horticulture Database, Ministry of Agriculture, Government of India, Gurgaon, New Delhi.

Pandit, M.K., Muthukumar, $\mathrm{P}$ and Mukhopadhyay, T.P. 2010. Study of genetic divergence through multivariate analysis in chilli (Capsicum annuum L.) germplasms. Journal of Interacademicia. 14 (3): 298-301
Patel, M.Z., Reddi, M.V., Rana, B.S and Reddy, B.J. 1989.Genetic divergence in safflower (Carthamus tinctorius L.). The Indian Journal of Genetics and Plant Breeding. 49(1): 113-118.

Prasad, N.B.C, Gururaj, H.B, Kumar, V, Giridhar, P, Parimalan, R, Sharma, A, Ravishankar, G.A. 2006. Influence of 8-methyl nonenoicacid on capsaicin biosyn- thesis in vivo and in vitro cell cultures of Capsicum spp. Journal of Agricultural and Food Chemistry. 54: 1854-1859.

Ramanujam, S., Tiwary, A.S and Mehra, R.B. 1974.Genetic divergence and hybrid performance in mungbean. Theoretical and Applied Genetics. 44(5): 211-214.

Rana, M., Sharma, R., Sharma, P., Bhardwaj, S.V., Sandeep Kumar., Navjot Singh, B.. Sharma, M and Rajesh, D. 2015. Studies on genetic variability and divergence in Capsicum for fruit yield and quality traits in North- Western Himalayas. Ecology Environment and Conservation. 21: 415-421

Ranganna, S. 1986.Handbook of analysis and quality control for fruits and vegetable products. $2^{\text {nd }}$ edition. p: 259. Tata McGraw Hill Publ Com, New Delhi, India.

Rao, C.R. 1952. Advanced Statistical Methods in Biometrical Research. John Wiley and Sons Inc., New York. 236-272.

Razzaq, A, Tariq, M.K, Asif, S, Sohail, K, Alam, Z. 2016. Genetic diversity and association analysis for different morphological traits in Capsicum annuum L. International Journal of Biomolecules and Biomedicine.5 (1): 20-28.

Reddy, A.C.P and Lokesh, B.R. 1992. Changes in catalase and ascorbic acid oxidase activity in response to lead nitrate treatments. Indian Journal of Plant Physiology. 34: 143-146. 
Roserbrook, D.D., Proize, C.C and Barney, J.E. 1968. Improved method for determination of extractable colour in capsicum spices. Journal of Association of Official Analytical Chemists. 51: 637643.

Sadasivam, S and Balasubramanian, T. 1987. Practical manual in Biochemistry. TNAU, Coimbatore, p: 14.

Shrilekha, M., Lal, R.K., Darokar, M.P and Khanuja, S.P.S. 2011. Genetic variability in germplasm accessions of Capsicum annuum L. American Journal of Plant Sciences. 2(5): 629-635.

Singh, R.K and Chaudhary, B.D. 1977.Biometrical Methods in Quantitative Genetic Analysis. Kalyani Publishers. New Delhi. pp 215-218.
Sumathy, K.M.A and Mathew, A.G. 1984. Chilli processing. Indian Cocoa, Arecanut and Spice Journal.7: 112-113. Suryakumari, S., Umajyothi, K., Srihari, D., Sankar, A.S and Sankar, C.R. 2010. Variability and genetic divergence in paprika (Capsicum annuum L.). Journal of Spices and Aromatic Crops. 19 (1 \& 2), 71-75.

Tasso, Y, Rakesh, K, Dubey, Vikas, S and Garima, U. 2014. Genetic diversity of chilli (Capsicum annuum L.) genotypes of India based on morpho-chemical traits. Australian Journal of Crop Science. 8(1): 97-102.

Vani, S.K., Sridevi, O and Salimath, P.M. 2007.Genetic divergence in chilli (Capsicum annuum L.). Annales de biologie Clinique. 23(2): 123-128.

\section{How to cite this article:}

Lakshmi Tirupathamma, T., L. Naram Naidu, C. Venkata Ramana and Sasikala, K. 2018. Genetic Divergence Studies in Paprika (Capsicum annuum L.). Int.J.Curr.Microbiol.App.Sci. 7(08): 199-215. doi: https://doi.org/10.20546/ijcmas.2018.708.027 